\title{
EFFECT OF SELECTED JACKFRUIT GENOTYPES ON QUALITY
}

\section{PARAMETERS OF SQUASH}

\author{
SHWETHA. M. $\mathrm{S}^{1} \&$ B. RANGANNA ${ }^{2}$
}

Department of Agricultural Engineering, University of Agricultural Sciences, G.K.V.K, Bangalore, Karnataka, India

Jackfruit (Artocarpusheterophyllus.L) genotypes, namely HV-1, Swarnahalasu, Muttomvarikka, Lalbaghmadhura and HRS were selected and processed into squash, and later analyzed for sensory properties for a period of 3 months at different storage conditions (ambient and refrigerated). The results of the study revealed that the squash stored under refrigerated temperature maintained all the sensory parameters such as color, flavor, taste, mouthfeel and overall acceptability throughout the storage period in refrigerated condition when compared to samples stored at ambient condition, which was stable up to one to 2 month in all selected genotypes. And finally, by taking all the properties into consideration, it was concluded that Muttomvarikka genotype was the best, followed by Lalbaghmadhura, respectively.
\end{abstract}

KEYWORDS: Jackfruit, Genotype, Squash, Sensory Analysis, Shelf-Life \& Storage

Received: Dec 15, 2017; Accepted: Jan 08, 2018; Published: Feb 05, 2018; Paper Id.: IJASRFEB201822

\section{INTRODUCTION}

The jackfruit tree is valued for its money earning capacity. There are instances in which, a single jackfruit tree is reported to provide an income of several thousand rupees in one season alone. Because of this reason, its cultivation is becoming quite popular among the small holder farming community. Jackfruits are being increasingly valued in the food front, especially for the poor classes of the society, to whom the jackfruit is well within their reach than most of the other fruits.

Of late, the jackfruit is being valued by the processors to make best use of the heaps and heaps of jackfruits, that gluts into the market during peak season of its harvest (March - May ). The score of jack products, i.e., processed (value added products), can be developed on commercial scale. The noteworthy among these products are: squash, nectar, fruit bar, toffy, jam, jelly, canned bulbs, dehydrated bulbs and a lot many (Thomas, 1980).

This endeavor helps not only to utilize the excess produce of jackfruits during the season, but also ensures the development of sustained jackfruit processing industry on cottage scale in the rural areas. When this dream comes true, the contribution of jackfruit to the food front will be immense.

Interestingly, it is not possible to convert fruits of all jackfruit trees into a variety of products due to immense variations of plant types in physical and biochemical qualities of fruits (Samaddar, 1985). Western Ghats, the treasure house of wide diversity of jackfruit, provides ample opportunities for survey, collection and evaluation of fruit quality for processed products and to identify the types suitable for different purposes. Product diversification in jackfruit helps in popularizing the fruit among the masses, as it removes difficulty in separating 
the bulbs from rind. Further, India has the potential to break a new ground and create market for indigenous fruits, where no other country can compete.

Sensory evaluation is the scientific method used to analyze and interpret reactions to those characteristics of food perceived by the senses of sight, smell, taste, touch, and hearing. Sensory qualities guide the consumers in their selection of foods and also help to determine the conformity of a food with established movement or trade standards and food grade.

Therefore, keeping in view the above things the developed squash from different genotypes were analyzed for sensory evaluation under trained panel, to come out with best jackfruit genotype suitable for processing into squash.

\section{MATERIAL AND METHODS}

Five popular jackfruit genotypes, namely, $H V-1$, SwarnaHalasu, Muttomvarikka, Lalbaghmadhura and Horticulture Research Station (HRS) were selected for developing squashes. Matured jackfruits of the above genotypes were procured from UAS, GKVK campus and from jackfruit growers in Doddaballapur Taluk of Bangalore Rural District, Karnataka.

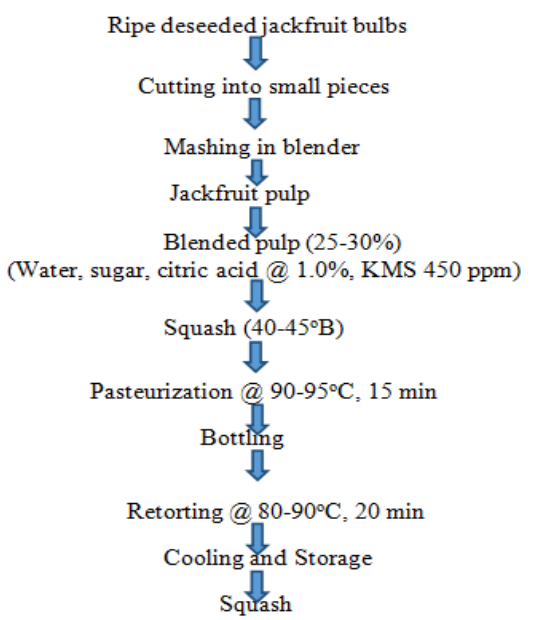

Figure 1: Flow Chart for Preparation of Jackfruit Squash

The processed jackfruit squashes from five genotypes developed as per FSSAI standards, and were analyzed for sensory parameters like color, flavor, taste, mouth-feel and overall acceptability. The experimental treatments are follows:

\begin{tabular}{|l|l|}
\hline & HV-1 (G1), \\
Jackfruit Genotypes (G) & $\begin{array}{l}\text { Swarnahalasu (G2), } \\
\text { Muttomvarikka (G3), } \\
\text { Lalbaghmadhura (G4) and } \\
\text { Horticulture Research Station (HRS) (G5) }\end{array}$ \\
\hline Packaging material & Glass bottles \\
\hline Preservatives & Potassium meta-bisulphate (KMS-350 ppm) \\
\hline Storage temperature & Ambient temperature $\left(28-30^{\circ} \mathrm{C}\right)$ \\
& Refrigeration temperature $\left(2-3^{\circ} \mathrm{C}\right)$ \\
\hline Storage period (D) & 90 days $(3$ months $)$ \\
\hline
\end{tabular}

\section{Organoleptic Evaluation}

Genotypic differences of jackfruit squash for organoleptic quality with respect to color/appearance, taste, flavor, mouth-feel and overall acceptability was studied on a 9 hedonic point scale by a panel of judges for the fresh jackfruit 
squash, and also at monthly interval for 3 months periods. Samples were ranked for quality parameters from higher to lower in descending order of acceptability, respectively.

\section{Statistical Analysis}

For the statistical analysis, Factorial Completely Randomized Design (FCRD) was adopted. Observations on various parameters were recorded with three replications. The data were analyzed and main and interaction effects were studied (Sundararaj et al., 1972).

\section{RESULTS AND DISCUSSIONS}

The changes in organoleptic properties of jackfruit squash stored under ambient and refrigerated temperatures are presented in Tables 1 to 5. The results showed that squashes were found to be acceptable up to 90 days of storage in respect of organoleptic characteristics namely, color, flavor, taste, mouth-feel and overall acceptability under refrigerated storage, as it maintained the required storage conditions. Whereas, sensory characteristics of squashes stored at ambient temperature were found to be significantly decreasing as the storage period progressed.

Squash prepared from G3 and G5 recorded highest scores of 8.0 each with respect to color, which might be due to higher level of juice content on characteristic appearance, followed by, G2, G4 and G1 stored under refrigerated storage. However, in case of ambient temperature storage, G3, G4 and G5 recorded highest sensory score of 7.0 followed by G2 and G1. Statistically, significant results appeared with respect to genotypes (G), number of storage days (D) and interactions between $\mathrm{G}$ and $\mathrm{D}$ at ambient temperature and whereas, in case of refrigerated storage significant results appeared with respect to genotypes $(\mathrm{G})$, but non-significant in respect of storage period (D) and interactions between $\mathrm{G}$ and D.

Table 1: Influence of Genotypes on Color of Jackfruit Squashes During Storage

\begin{tabular}{|c|c|c|c|c|c|c|c|c|c|c|}
\hline \multirow{4}{*}{ Genotype (G) } & \multicolumn{10}{|c|}{ Color } \\
\hline & \multicolumn{10}{|c|}{ Storage Period (Days) } \\
\hline & \multicolumn{4}{|c|}{ Ambient Temperature (D) } & \multirow[t]{2}{*}{ Mean } & \multicolumn{4}{|c|}{ Refrigerated Temperature (D) } & \multirow[t]{2}{*}{ Mean } \\
\hline & $\mathbf{0}$ & 30 & 60 & 90 & & 0 & 30 & 60 & 90 & \\
\hline G-1 & 7.00 & 6.91 & 5.00 & - & 6.30 & 7.00 & 7.00 & 7.00 & 7.00 & 7.00 \\
\hline G-2 & 8.00 & 7.83 & 6.83 & - & 7.55 & 8.00 & 8.00 & 7.83 & 8.00 & 7.95 \\
\hline G-3 & 8.00 & 7.60 & 7.00 & - & 7.53 & 8.00 & 8.30 & 8.00 & 7.90 & 8.05 \\
\hline G-4 & 8.00 & 7.90 & 7.00 & - & 7.63 & 8.00 & 8.00 & 7.90 & 7.80 & 7.92 \\
\hline G-5 & 8.00 & 7.90 & 7.00 & - & 7.63 & 8.00 & 8.00 & 8.00 & 8.00 & 8.00 \\
\hline Mean & 7.80 & 7.62 & 6.56 & - & - & 7.800 & 7.860 & 7.746 & 7.740 & - \\
\hline
\end{tabular}

\begin{tabular}{|l|c|c|c|c|c|c|}
\hline \multirow{2}{*}{ Statistical Analysis } & \multicolumn{3}{|c|}{ Ambient Temperature } & \multicolumn{3}{c|}{ Refrigerated Temperature } \\
\cline { 2 - 7 } & G & D & G×D & G & D & G×D \\
\hline F-test & $*$ & $*$ & $*$ & $*$ & NS & NS \\
\hline SEm \pm & 0.0953 & 0.0738 & 0.1651 & 0.0895 & 0.0800 & 0.1790 \\
\hline CD at 5\% & 0.2641 & 0.2046 & 0.4575 & 0.2480 & - & - \\
\hline CV $(\%)$ & \multicolumn{3}{|c|}{7.1202} & \multicolumn{3}{|c|}{7.2685} \\
\hline
\end{tabular}

* Significant at 5\%, NS - Non-Significant, G - Genotypes, D - Days

With respect to flavor, G3 and G5 rank first with highest score of 7.80, followed by G4, G1 and G2 stored under refrigerated temperature. However, in case of ambient temperature, G2 (6.83) recorded the highest followed by G3, G5, G4 and G1. Hall and Edward (1989) reported that the processed foods lose to some extent nutrients, especially vitamins, flavoring and aroma compounds, amino acids, sugars, etc., during processing and subsequently during storage period. 
Flavor decreased significantly with respect to genotypes (G) and non-significantly with storage period (D) and interactions between $\mathrm{G}$ and $\mathrm{D}$ in the refrigerated storage. In ambient storage, flavor decreased significantly with $\mathrm{G}$ and $\mathrm{D}$ and nonsignificantly with interactions between $\mathrm{G}$ and $\mathrm{D}$.

Table 2: Influence of Genotypes on 'Flavor' of Jackfruit Squashes during Storage

\begin{tabular}{|c|c|c|c|c|c|c|c|c|c|c|}
\hline \multirow{4}{*}{ Genotype (G) } & \multicolumn{10}{|c|}{ Flavor } \\
\hline & \multicolumn{10}{|c|}{ Storage Period (Days) } \\
\hline & \multicolumn{4}{|c|}{ Ambient Temperature (D) } & \multirow[t]{2}{*}{ Mean } & \multicolumn{4}{|c|}{ Refrigerated Temperature (D) } & \multirow[t]{2}{*}{ Mean } \\
\hline & 0 & 30 & 60 & 90 & & 0 & 30 & 60 & 90 & \\
\hline G-1 & 7.60 & 7.22 & 6.22 & - & 7.01 & 7.60 & 7.60 & 7.60 & 7.00 & 7.45 \\
\hline G-2 & 7.50 & 7.00 & 6.83 & - & 7.11 & 7.50 & 7.50 & 7.50 & 7.00 & 7.37 \\
\hline G-3 & 8.00 & 7.20 & 6.80 & - & 7.33 & 8.00 & 8.00 & 7.80 & 7.80 & 7.90 \\
\hline G-4 & 7.30 & 7.05 & 6.50 & - & 6.95 & 7.30 & 7.30 & 7.15 & 7.16 & 7.22 \\
\hline G-5 & 7.80 & 7.50 & 6.70 & - & 7.33 & 7.80 & 7.80 & 7.80 & 7.80 & 7.80 \\
\hline Mean & 7.64 & 7.19 & 6.61 & - & - & 7.64 & 7.64 & 7.57 & 7.35 & - \\
\hline
\end{tabular}

\begin{tabular}{|l|c|c|c|c|c|c|}
\hline \multirow{2}{*}{ Statistical Analysis } & \multicolumn{3}{|c|}{ Ambient Temperature } & \multicolumn{3}{c|}{ Refrigerated Temperature } \\
\cline { 2 - 7 } & G & D & G×D & G & D & G $\times$ D \\
\hline F-test & $*$ & $*$ & NS & $*$ & NS & NS \\
\hline SEm \pm & 0.0993 & 0.0769 & 0.1720 & 0.0963 & 0.0862 & 0.1927 \\
\hline CD at 5\% & 0.2752 & 0.2132 & - & 0.2670 & - & - \\
\hline CV $(\%)$ & \multicolumn{3}{|c|}{7.6093} & \multicolumn{4}{c|}{8.0699} \\
\hline
\end{tabular}

* Significant at 5\%, NS - Non-Significant, G - Genotypes, D - Days

Squash of G5 recorded highest score of 8.0 with respect to taste, followed by G1, G3, G2 and G4 stored in refrigerated storage. In case of ambient storage, G1 and G2 recorded the highest score of 7.0 followed by G3, G5, and G4. Tastes found decreasing significantly with respect to genotypes (G) and storage period (D) and non-significantly with interactions between $\mathrm{G}$ and $\mathrm{D}$ in refrigerated storage. At ambient storage, tastes decreased significantly with D and nonsignificantly with G and interactions between G and D. Similar studies were observed by Jain et al., (1984).

Table 3: Influence of Genotypes on 'Taste' of Jackfruit Squashes during Storage

\begin{tabular}{|c|c|c|c|c|c|c|c|c|c|c|}
\hline \multirow{4}{*}{$\begin{array}{l}\text { Genotype } \\
\text { (G) }\end{array}$} & \multirow{2}{*}{\multicolumn{10}{|c|}{$\begin{array}{c}\text { Taste } \\
\text { Storage Period (Days) }\end{array}$}} \\
\hline & & & & & & & & & & \\
\hline & \multicolumn{4}{|c|}{$\begin{array}{l}\text { Ambient Temperature } \\
\text { (D) }\end{array}$} & \multirow[t]{2}{*}{ Mean } & \multicolumn{4}{|c|}{$\begin{array}{l}\text { Refrigerated Temperature } \\
\text { (D) }\end{array}$} & \multirow[t]{2}{*}{ Mean } \\
\hline & 0 & 30 & 60 & 90 & & 0 & 30 & 60 & 90 & \\
\hline G-1 & 8.00 & 7.83 & 7.00 & - & 7.61 & 8.00 & 8.00 & 8.00 & 7.91 & 7.977 \\
\hline G-2 & 7.50 & 7.31 & 7.00 & - & 7.27 & 7.50 & 7.50 & 7.40 & 7.40 & 7.450 \\
\hline G-3 & 8.00 & 7.20 & 6.83 & - & 7.34 & 8.00 & 8.00 & 8.00 & 7.90 & 7.970 \\
\hline G-4 & 8.10 & 7.60 & 6.50 & - & 7.40 & 8.10 & 8.10 & 7.60 & 7.25 & 7.762 \\
\hline G-5 & 8.00 & 7.80 & 6.70 & - & 7.50 & 8.00 & 8.00 & 8.00 & 8.00 & 8.00 \\
\hline Mean & 7.92 & 7.54 & 6.80 & - & - & 7.92 & 7.92 & 7.80 & 7.69 & - \\
\hline
\end{tabular}

\begin{tabular}{|l|c|c|c|c|c|c|}
\hline \multirow{2}{*}{ Statistical Analysis } & \multicolumn{3}{|c|}{ Ambient Temperature } & \multicolumn{3}{c|}{ Refrigerated Temperature } \\
\cline { 2 - 7 } & G & D & G×D & G & D & G $\times$ D \\
\hline F-test & NS & $*$ & NS & $*$ & $*$ & NS \\
\hline SEm \pm & 0.1109 & 0.0859 & 0.1922 & 0.0733 & 0.0655 & 0.1465 \\
\hline CD at 5\% & - & 0.2382 & - & 0.2030 & 0.1816 & - \\
\hline CV $(\%)$ & \multicolumn{3}{|c}{8.1845} & \multicolumn{3}{c|}{5.9145} \\
\hline
\end{tabular}

* Significant at 5\%, NS - Non Significant, G - Genotypes, D - Days

In case of sensory evaluation of mouth-feel, squash from G1 recorded the highest score of 7.91 followed by G3 and G5, G4 and G2 stored in refrigerated temperature. In case of ambient storage, G2, G3, G4 and G5 recorded highest 
scores of 6.83 each followed by G1. It decreased significantly with respect to genotypes (G) and storage period (D), and non-significantly with interactions between $\mathrm{G}$ and $\mathrm{D}$ in refrigerated storage. At ambient storage, the tastes decreased significantly with $\mathrm{D}$ and $\mathrm{G} \times \mathrm{D}$ and non- significantly with $\mathrm{G}$.

Table 4: Influence of Genotypes on 'Mouth-Feel' of Jackfruit Squash during Storage

\begin{tabular}{|c|c|c|c|c|c|c|c|c|c|c|}
\hline \multirow{4}{*}{ Genotype (G) } & \multicolumn{10}{|c|}{ Mouth-Feel } \\
\hline & \multicolumn{10}{|c|}{ Storage Period (Days) } \\
\hline & \multicolumn{4}{|c|}{$\begin{array}{l}\text { Ambient Temperature } \\
\text { (D) }\end{array}$} & \multirow[t]{2}{*}{ Mean } & \multicolumn{4}{|c|}{ Refrigerated Temperature (D) } & \multirow[t]{2}{*}{ Mean } \\
\hline & 0 & 30 & 60 & 90 & & 0 & 30 & 60 & 90 & \\
\hline G-1 & 8.00 & 7.83 & 6.00 & - & 7.27 & 8.00 & 8.00 & 8.00 & 7.91 & 7.97 \\
\hline G-2 & 7.55 & 7.38 & 6.83 & - & 7.25 & 7.50 & 7.55 & 7.55 & 6.83 & 7.35 \\
\hline G-3 & 8.00 & 7.70 & 6.83 & - & 7.51 & 8.00 & 8.00 & 8.00 & 7.80 & 7.95 \\
\hline G-4 & 7.90 & 7.55 & 6.83 & - & 7.42 & 7.90 & 7.90 & 7.55 & 7.22 & 7.64 \\
\hline G-5 & 7.90 & 7.70 & 6.83 & - & 7.47 & 7.90 & 7.90 & 7.80 & 7.80 & 7.85 \\
\hline Mean & 7.87 & 7.63 & 6.66 & - & - & 7.86 & 7.87 & 7.78 & 7.51 & - \\
\hline
\end{tabular}

\begin{tabular}{|l|c|c|c|c|c|c|}
\hline \multirow{2}{*}{ Statistical Analysis } & \multicolumn{3}{|c|}{ Ambient Temperature } & \multicolumn{3}{c|}{ Refrigerated Temperature } \\
\cline { 2 - 7 } & G & D & G×D & G & D & G $\times \mathbf{D}$ \\
\hline F-test & NS & $*$ & $*$ & $*$ & $*$ & NS \\
\hline SEm \pm & 0.1097 & 0.0850 & 0.1900 & 0.0929 & 0.0831 & 0.1858 \\
\hline CD at 5\% & - & 0.2355 & 0.5267 & 0.2575 & 0.2303 & - \\
\hline CV $(\%)$ & \multicolumn{3}{|c|}{8.1331} & \multicolumn{4}{c|}{7.5773} \\
\hline
\end{tabular}

* Significant at 5\%, NS - Non Significant, G - Genotypes, D - Days

Squash developed from G3 recorded the highest score of 8.00 in respect of overall acceptability, followed by G5, G1, G2 and G4 stored under refrigerated storage. In case of ambient storage, G4 recorded highest score of 6.81 followed by G5, G2 and G3 and G1. In both the storages, sensory scores of overall acceptability decreased significantly with respect to genotypes $(\mathrm{G})$ and non-significantly with storage period (D) and interactions between G and D.

Table 5: Influence of Genotypes on 'Overall Acceptability' of Jackfruit Squashes during Storage

\begin{tabular}{|c|c|c|c|c|c|c|c|c|c|c|}
\hline \multirow{3}{*}{ Genotype (G) } & \multicolumn{10}{|c|}{$\begin{array}{l}\text { Overall Acceptability } \\
\text { Storage Period (Days) }\end{array}$} \\
\hline & \multicolumn{4}{|c|}{ Ambient Temperature (D) } & \multirow[t]{2}{*}{ Mean } & \multicolumn{4}{|c|}{ Refrigerated Temperature (D) } & \multirow[t]{2}{*}{ Mean } \\
\hline & $\mathbf{0}$ & 30 & 60 & 90 & & $\mathbf{0}$ & 30 & 60 & 90 & \\
\hline G-1 & 8.00 & 7.00 & 6.00 & - & 7.00 & 8.00 & 8.00 & 8.00 & 7.88 & 7.97 \\
\hline G-2 & 7.60 & 7.38 & 6.70 & - & 7.22 & 7.60 & 7.60 & 7.60 & 7.44 & 7.56 \\
\hline G-3 & 8.00 & 7.75 & 6.70 & - & 7.48 & 8.00 & 8.00 & 8.00 & 8.00 & 8.00 \\
\hline G-4 & 7.95 & 7.65 & 6.81 & - & 7.47 & 7.85 & 7.95 & 7.55 & 7.32 & 7.66 \\
\hline G-5 & 7.95 & 7.72 & 6.80 & - & 7.49 & 7.95 & 7.95 & 7.90 & 7.90 & 7.92 \\
\hline Mean & 7.90 & 7.50 & 6.60 & - & - & 7.88 & 7.90 & 7.81 & 7.70 & - \\
\hline
\end{tabular}

\begin{tabular}{|l|c|l|c|c|c|c|}
\hline \multirow{2}{*}{ Statistical Analysis } & \multicolumn{3}{|l|}{ Ambient Temperature } & \multicolumn{3}{l|}{ Refrigerated Temperature } \\
\cline { 2 - 7 } & G & D & G×D & G & D & G×D \\
\hline F-test & $*$ & NS & NS & $*$ & NS & NS \\
\hline SEm \pm & 0.1025 & 0.0794 & 0.1775 & 0.0953 & 0.0853 & 0.1906 \\
\hline CD at 5\% & 0.2840 & 0.2200 & - & 0.2642 & - & - \\
\hline CV $(\%)$ & \multicolumn{3}{|c}{7.6523} & \multicolumn{3}{c|}{7.7049} \\
\hline
\end{tabular}

* Significant at 5\%, NS - Non Significant, G - Genotypes, D - Days 


\section{CONCLUSIONS}

The results revealed that the preservative and packaging material used was very much effective in enhancing shelf life of squash, and squash was found to be acceptable for a period of 90 days with respect to all organoleptic characteristics such as color, flavor, taste, mouth-feel and overall acceptability, up to 3 months of storage period under refrigerated storage. Whereas, squash stored at ambient temperature was significantly decreased, however some parameters showed no significance among genotypes $(G)$, storage period (D) and interactions $(G \times D)$, statistically.

\section{REFERENCES}

1. Hall, M Nand Edward, M C.1989. Effect of processing on food quality. ActaHort., 244: 217-226.

2. Jain, $S$ P., Thripathi, V K and Ram, H B. 1984. Studies on storage behavior of orange, lemon and bael squashes. Indian Food Packer, 38(5): 33-39.

3. Samaddar, H N. 1985. Jackfruit. In: Bose T K. (Ed.), Fruits of India: Tropical and Subtropical. MitraNayaProkash Publishers, Calcutta, India. pp 487-497, 638-649.

4. Sanjay Agarwal et al., Influence of Saline Water Irrigation on Crude Protein and Amino Acids in Two Genotypes of Finger Millet (Eleusine Coracana Gaertn), International Journal of Agricultural Science and Research (IJASR), Volume 6, Issue 5, September - October 2016, pp. 261-268

5. Sundararaj, N., Nagaraju, S., Venkataramana, M N and Jagannath, M K. 1972. Design and analysis of field experiments, University of Agricultural Sciences, Bangalore.

6. Thomas, C A. 1980. Jackfruit as source of food and income. Econs.Bot.34(2):154-159. 